BOTANICA

ISSN 2538-8657

2020, 26(1): 88-94

\title{
REVISION OF THE GENUS CETRELIA (LICHENISED ASCOMYCOTA) IN LATVIA
}

\author{
Polina Degtuarenko ${ }^{1,2^{*}}$, Rolands Moisejevs ${ }^{2}$ \\ ${ }^{1}$ University of Tartu, Department of Botany, Lai Str. 40, 51005 Tartu, Estonia \\ ${ }^{2}$ Daugavpils University, Institute of Life Sciences and Technology, Parādes Str. 1a, 5401 Daugavpils, Latvia* \\ Corresponding author. E-mail: polina.degtjarenko@ut.ee
}

\begin{abstract}
Degtjarenko P., Moisejevs R., 2020: Revision of the genus Cetrelia (lichenised Ascomycota) in Latvia. - Botanica, 26(1): 88-94.

All available specimens (98) of the genus Cetrelia from Latvia (Northern Europe) in the Herbaria DAU and RIG were revised. Cetrelia cetrarioides, C. olivetorum and C. monachorum were confirmed to occur in the country. The last taxon is new to Latvia. Distribution maps and habitat preferences of all three species in Latvia were presented, and their conservation status was discussed.
\end{abstract}

Keywords: cetrarioid lichens, Cetrelia monachorum, chemotypes, conservation, new record, Parmeliaceae.

\section{INTRODUCTION}

The genus Cetrelia W.L. Culb. \& C.F. Culb. (Parmeliaceae, Lecanorales, Ascomycota) has been described by CULBERSON \& CULBERSON (1968). The genus is characterised by a large foliose, loosely attached greyish-green thallus with rounded marginal lobes and laminal pseudocyphellae on an upper cortex, at least partly black lower surface with sparse rhizines, ellipsoid ascospores, and atranorin as the main cortical substance with different orcinol depsides and depsidones as diagnostic medullary substances (Culberson \& Culberson, 1968, 1976; Obermayer \& MAyrhofer, 2007; Mark et al., 2019). The European Cetrelia species are characterised by the presence of marginal soralia. In Europe, the $\mathrm{Ce}$ trelia species are mostly epiphytic and found in old natural or seminatural forests on tree bark or occasionally on mossy rocks (OBERMAYER \& MAYRHOFFer, 2007; Kukwa et al., 2012; Degtuarenko et al., 2018). The genus includes 18 currently accepted species (Thell et al., 2012; RANDLANE et al., 2013), and most species are restricted to eastern and southeastern Asia (Culberson \& Culberson, 1968; RandLANE \& SAAG, 1991). In Europe, only four species are known: Cetrelia cetrarioides (Delise) W.L. Culb. \& C.F. Culb., Cetrelia chicitae (W.L. Culb.) W.L. Culb. \& C.F. Culb., Cetrelia monachorum (Zahlbr.) W.L. Culb. \& C.F. Culb., and Cetrelia olivetorum (Nyl.) W.L. Culb. \& C.F. Culb. (Culberson \& Culberson, 1968; Hawksworth et al., 2008, 2011). The taxonomic affinities of these species have been discussed over the years. Several studies have suggested accepting only one species in the group with four chemotypes, separated according to the major medullary substances, which can be visualised by the standard thin-layer chromatography methods (TLC) (Clere, 2004; Santesson et al., 2004; Gilbert \& Purvis, 2009), while others have considered the different chemotypes as separate species (RANDLANE \& SAAG, 1991; Wirth et al., 2013). Recently, MarK et al. (2019) have shown that these chemotypes are correlated with phylogenetic clades. Recognition of the species based on TLC results is, therefore, confirmed to be possible. The Cetrelia synthesise specific sets of related substances - chemosyndromes, where the same product may occur in several species, but in different quantities, acting either as a major or a minor compound - specific to its taxonomic affiliation (Culberson \& Culberson, 1968). Cetrelia monacho- 
rum contains imbricaric acid as the major medullary substance and, additionally perlatolic, 4-O-demethylimbricaric, and anziaic acids in minor or trace amounts in the medulla (OBERMAYER \& MAYrhofer, 2007; Kukwa \& Motiesūnaité, 2012). Cetrelia cetrarioides contains perlatolic acid as the major and imbricaric acid as minor medullary substance (OBERMAYER \& MAYrhofer, 2007; KuKWA \& MotieJŪNAitĖ, 2012). Cetrelia olivetorum can be separated from the morphologically similar species $C$. cetrarioides and C. monachorum by a strong sanguineous/red reaction with the spot-test reaction with solution of sodium hypochlorite $(\mathrm{C})$, which is caused by the presence of olivetoric acid in medulla (with trace of anziaic acid and 4-O-de-methylmicrophyllinic acid) (OBERMAYER \& Mayrhofer, 2007; Golubkov et al., 2015). Cetrelia chicitae produces alectoronic acid and a-collatolic acid, including physodic acid and 4-O-methylphysodic acid in traces (OBERMAYER \& MAYRHOFER, 2007). Also, all discussed Cetrelia species contain atranorin in the cortex.

In Latvia, two species, C. olivetorum and C. cetrarioides, have been recorded and distinguished by morphology and a spot-test reaction with solution of sodium hypochlorite (C) (ĀBolin̦A et al., 2015). In the neighbouring countries, Estonia, Lithuania and Belarus, three species of the genus Cetrelia have been confirmed by TLC (KuKwa \& Motiejūnaite, 2012; GolubKov et al., 2015; Degtjarenko et al., 2018). To date, no particular chemical studies using TLC and distributional survey of the genus Cetrelia have been performed in Latvia. This study aimed to revise the Cetrelia taxa from available herbarium material to determine the species, their distribution and habitat preferences according to the European Union Habitats Directive in Latvia.

\section{MATERIALS AND METHODS}

The present study was based on herbarium material collected in Latvia from 1957 to 2018. A total of 98 specimens from the Lichenological Herbarium of Daugavpils University (DAU) and the University of Latvia (RIG) were studied. Morphology of the Cetrelia specimens was examined using a stereomicroscope. The specimens were tested for lichen substances by thin-layer chromatography (TLC; solvent A) (ORANGE et al., 2001). Localities of Latvian specimens and their substrates were transcribed from the labels. Distribution maps of the Cetrelia species were created using ESRI ArcGIS pro 2.3. (ESRI, 2011).

\section{RESULTS AND DISCUSSION}

Heretofore, only two species, Cetrelia olivetorum and C. cetrarioides, had been known in Latvia (ĀBolina et al., 2015), Cetrelia monachorum was reported new to Latvia. Cetrelia cetrarioides and C. olivetorum accounted for $43 \%$ and $42 \%$ of the examined specimens, respectively. Amongst other Cetrelia species in Latvia, Cetrelia monachorum appeared to be the rarest - with $15 \%$ of the examined specimens. All studied material was sterile (without apothecia).

Cetrelia cetrarioides and C. olivetorum were first recorded in Latvia in 1957 (ANDRUŠAITIS et al., 1996) in the Numerne Forest near Donikava town. Since then, it has been recorded from other parts of Latvia as well (Piterāns, 2001; ĀBoliñA et al., 2015). Most collections of the Cetrelia are from the north-eastern and central parts of Latvia (Figs 1,2). There are no records from the western part of the country. The distribution of $C$. monachorum is congruent with the distribution of other Cetrelia species (Fig. 3).

The three Cetrelia taxa are morphologically very similar, and difficult to distinguish based on morphology alone (RAndlane \& SAag, 1991; Obermayer \& MAYrhofer, 2007; MARK et al., 2019). In our study, twenty-one $C$. cetrarioides specimens were previously determined as $C$. olivetorum, and seven $C$. olivetorum specimens as $C$. cetrarioides. A possible explanation

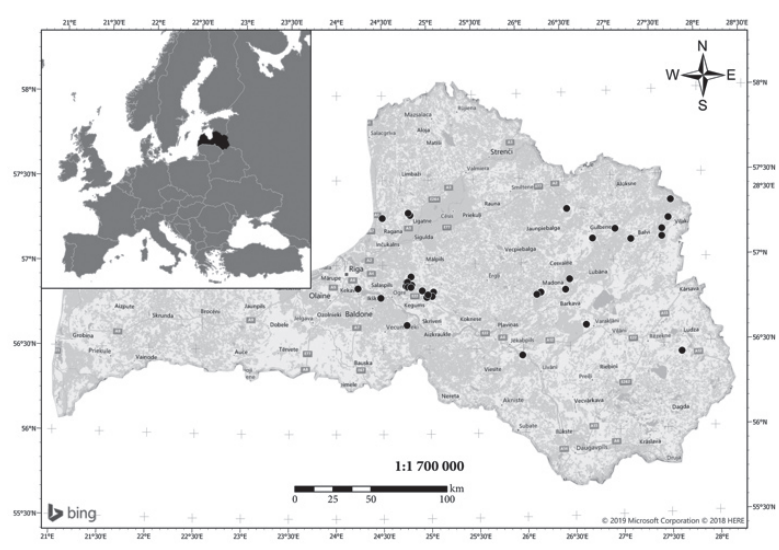

Fig. 1. Map of Cetrelia cetrarioides distribution in Latvia (marked with black circles); based on the herbarium collection from 1957 to 2018 


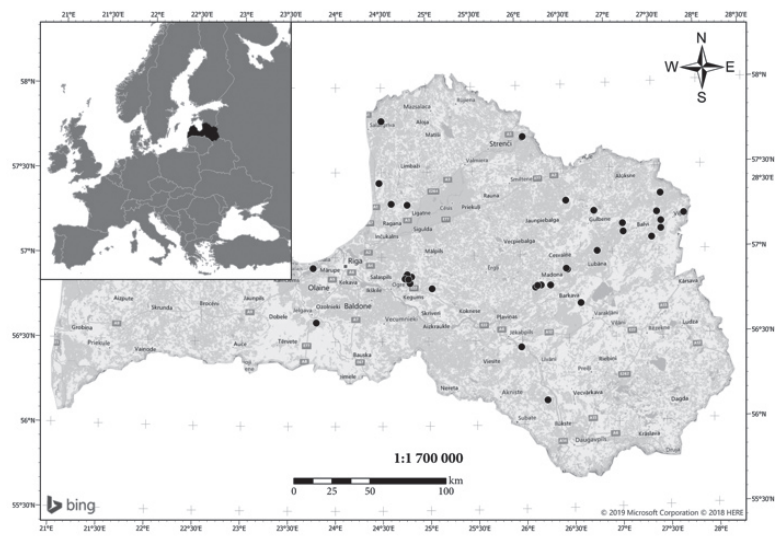

Fig. 2. Map of Cetrelia olivetorum distribution in Latvia (marked with black circles); based on the herbarium collection from 1957 to 2018

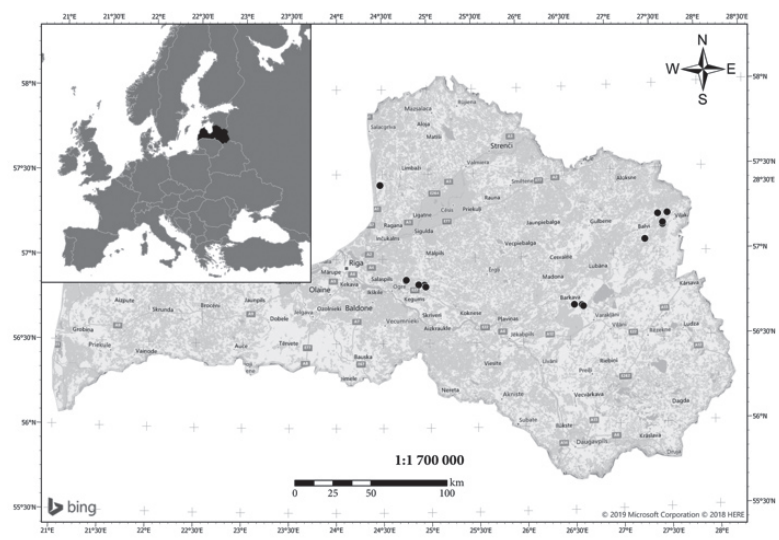

Fig. 3. Map of Cetrelia monachorum distribution in Latvia (marked with black circles); based on the herbarium collection from 1957 to 2018

for this might be that $C$. olivetorum and $C$. cetrarioides had been treated in Latvia as one species until 2001 (PITERĀNS, 2001). Since 2001, the determination of these taxa continued to be mainly based on morphology and spot-test reactions which are unreliable. Fifteen specimens were determined as C. monachorum (previously determined as C. cetrarioides and C. olivetorum and kept in the herbarium collections under $C$. cetrarioides or $C$. olivetorum names). The determination of lichen secondary substances using TLC proved to be a reliable tool to distinguish between these taxa (OBERMAYER \& MAYRHOFER, 2007; KuKwa et al., 2012; MARK et al., 2019).

In the continental parts of Europe, the Cetrelia species grow mostly in old deciduous or mixed forests, in localities of high humidity (OBERMAYER \& MAYRHOFFER, 2007), especially in swamp forests or forests surrounded by a lake or river or on hillsides near lakes or streams (RANDLANE \& SAAG, 1991; Kukwa et al., 2012; KuKwa \& Motiejūnaité, 2012). The Cetrelia habitat requirements in Latvia according to the European Union Habitats Directive (Auninš et al., 2013) were based only on 33 recorded specimens from DAU and RIG. Data on habitat requirements according to the EU Habitats Directive were not used for other 65 specimens due to insufficient data on the specimen labels and lack of knowledge on the EU habitat distribution in Latvia. The examined Cetrelia specimens were mainly found at the sites, which correspond to the habitat type "Fennoscandian hemiboreal natural old broad-leaved deciduous forests (Quercus, Tilia, Acer, Fraxinus or Ulmus) rich in epiphytes" (habitat type code "9020", 31\% of the examined records), "Fennoscandian deciduous swamp forests" (habitat type code " $9080 *$ ", $24 \%$ of the examined records), and "Alluvial forests with Alnus glutinosa and Fraxinus excelsior" (habitat type code "91E0*", 24\% of the examined records).

Elsewhere, the Cetrelia species usually occur on deciduous trees and are very rarely found on coniferous trees (OBERMAYER \& MAYRHOFFER, 2007; KUKWA et al., 2012; KuKwA \& MotiesūNAITE, 2012). In Latvia, the Cetrelia species prefer mostly Alnus glutinosa, Fraxinus excelsior, Populus tremula, Tilia cordata, Quercus robur and less frequently A. incana, Betula pendula, Corylus avelana, Padus avium and Picea abies (Table 1). The habitat preferences for 18 specimens were not recorded on the specimen labels (Table 1).

In the Baltic countries, the Cetrelia species are rare and threatened. In Estonia, C. olivetorum and C. cetrarioides are considered as endangered (EN) and C. monachorum as critically endangered (CR; LõHMUs et al., 2019). In Lithuania, all species of the genus $\mathrm{Ce}$ trelia are considered as EN (Jurga Motiejūnaite pers. comm.). In Fennoscandia, for example, in Sweden, C. olivetorum s. lat. is treated as CR (NoRDIN et al., 2011; Artfakta, 2019), and in Finland, C. olivetorum - as EN (HYVÄRINEN et al., 2019). In neighbouring Belarus, $C$. olivetorum and $C$. monachorum are treated as EN, and C. cetrarioides - as CR (BELY et al., 2014). Cetrelia olivetorum is classified in Category I of the Latvian Red Data Book; the assessment of status was based on only seven herbarium specimens and one historical record (ANDRUŠAITIS et al., 1996). The status of newly reported C. monachorum has not been 
Table 1. Substrate requirements for Cetrelia cetrarioides, Cetrelia monachorum and Cetrelia olivetorum in Latvia; based on the herbarium collection from DAU and RIG

\begin{tabular}{|l|c|c|c|c|}
\hline Substrate & C. cetrarioides & C. monachorum & C. olivetorum & Total \\
\hline Alnus glutinosa & 13 & 4 & 12 & 29 \\
\hline Alnus incana & 2 & 1 & 1 & 4 \\
\hline Betula spp. & 2 & 0 & 1 & 3 \\
\hline Corylus avelana & 0 & 0 & 1 & 1 \\
\hline Populus tremula & 2 & 0 & 3 & 5 \\
\hline Fraxinus excelsior & 11 & 2 & 7 & 1 \\
\hline Picea abies & 1 & 0 & 5 & 9 \\
\hline Tilia cordata & 1 & 3 & 3 & 6 \\
\hline Quercus robur & 0 & 3 & 0 & 2 \\
\hline Padus avium & 1 & 1 & 8 & \\
\hline Unknown & 8 & 2 & & \\
\hline
\end{tabular}

determined yet. C. olivetorum is also included into the Legislative List (Rules of Ministry Cabinet) of Legally Protected Lichens in Latvia (Regulations, 2013). For the current species, micro-reserves of up to 30 ha might be established. The assessment of a threat status of Latvian Cetrelia species based on IUCN system (STANDARDS..., 2006) has not been performed yet. Further work needs to be carried out to assess the threat status of all three Cetrelia species in Latvia according to the IUCN system and reconsider their conservation status for the Latvian Legislative List of Legally Protected Lichens. It is also recommendable to include C. olivetorum, C. monachorum and C. cetrarioides into a species monitoring system (BARONIN̦A, 2017) to estimate the size of species populations and potential threats for all three species.

\section{Record new to Latvia}

Cetrelia monachorum (Zahlbr.) W.L. Culb. \& C.F. Culb.

C. monachorum is morphologically similar to other sorediate species of the genus Cetrelia and is characterised by the presence of (mainly) marginal soredia. The soralia of C. monachorum are often coarse and irregular in shape with soredia usually exceeding $40 \mu \mathrm{m}$ in diam. On the upper part of cortex, typically small and raised pseudocyphellae are found, sometimes associated with large ones, the lower cortex often lacks pseudocyphellae (CulBerson \& Culberson, 1968, 1976; Obermayer \& Mayrhofer, 2007). Morphologically similar sorediate Cetrelia species (C. cetrarioides, $C$. chicitae and $C$. olivetorum) are distinguished from $C$. monachorum by their different content sec- ondary metabolites profile (OBERMAYER \& MAYRHOFER, 2007; RAndlane \& SAAG, 1991; Mark et al., 2019). The species is known in the following European countries: Austria (OBermayer \& MAYrhofer, 2007), Belarus (Golubkov et al., 2015), Bosnia-Herzegovina (Bilovitz \& Mayrhofer, 2011), the Czech Republic (Obermayer \& Mayrhofer, 2007), Estonia (DegtJARENKo et al., 2018), France, Germany, Italy (OBERMAYer \& MAYrhofer, 2007), Lithuania (KuKwa \& Motiejūnaite, 2012), Montenegro (OBermayer \& Mayrhofer, 2007; KNezevic \& MAYrhofer, 2009), Norway (OBermayer \& Mayrhofer, 2007), Poland (Kukwa et al., 2012), Portugal (Llimona \& HLadun, 2001), Romania (Obermayer \& Mayrhofer, 2007), Russia (European part, Tver Oblast, STEPANCHIKOVA et al., 2011), Slovakia, Slovenia, (OBERMAYer \& MAYrhofer, 2007), Spain (BArbero et al., 1995), Sweden (Nordin et al., 2011), Switzerland (OBERmayER \& MAYrhofer, 2007), Ukraine (KoNDRATYUK et al., 2003), the United Kingdom (OBERMAYer \& MAYrHofER, 2007). It is also known from the Republic of Armenia, the Republic of Azerbaijan (SoHrabi et al., 2007), China (Wei, 1991), Georgia (OBermayer \& MAYrhofER, 2007; SohraBi \& Alstrup, 2007), Hawaii (Elix \& McCARTHy, 1998), India (Mishra \& Upreti, 2015), Japan (Kurokawa, 2003), North American mainland (OBermayer \& MAYrhofer, 2007), and from the Asian part of Russia (URBANAVICHUS \& ANDREEV, 2010).

Specimens examined. Ogres distr., Suntažu Forest, forest square -88 , forest site 5 , on unknown substrate, 16 Oct. 2002, I. Grīsle (RIG15910). Viḷakas distr., Žīguru Forest, forest square - 504, forest site 2, on A. glutinosa, 2 Oct. 2012, V. Lārmanis (RIG16132). 
Ogres distr., Suntažu Forestry, forest square - 256, forest site 12, on A. glutinosa, 16 Oct. 2002, I. Grīsle (RIG15925). Ogres distr., Suntažu Forestry, forest square -79 , forest site 8 , on A. incana, 16 Oct 2002, I. Grīsle (RIG15917). Balvu distr., Kupravas Forest on T. cordata, 3 Oct. 1996, A. Piterāns (RIG14313). Balvu distr., Tilža, Dominava Forest of high humidity on $F$. excelsior, 13 Aug. 1957, A. Piterāns (RIG2038). Balvu distr., Kupravas Forest on T. cordata, 3 Oct. 1996, A. Piterāns (without number). Ogres distr., Suntažu Forestry, forest square - 274, forest site 10 on unknown substrate, in 2002, I. Grīsle (RIG15905). Ogres distr., Suntažu Forestry, forest square - 157, forest site 8, on A. glutinosa, 1 Dec. 2002, I. Grīsle (RIG15908). Madonas distr., Barkavas Rural Municipality, on Q. robur, 22 May 1997, A. Piterāns (RIG15353). Madonas distr., on Q. robur, 22 May 1997, A. Piterāns (RIG15352). Madonas distr., Nature 'Barkavs ozolu audze', Q. robur forest, 22 May 1997, A. Piterāns (RIG15245). Balvu distr., Vīksnas Rural Municipality, Nature Reserve 'Kupravas liepu audze', T. cordata forest, 26 May 1976, A. Piterāns (RIG15244). Salacgrīvas distr., $2 \mathrm{~km}$ to the east of Mustkalni town, on A. glutinosa in alluvial swamp forest (91E0*), 1 July 2017, R. Moisejevs (DAU600000477). Krimulda distr., about $3 \mathrm{~km}$ of Lèdurga town to the east, on $F$. excelsior, in oldgrowth broadleaved forest dominated by $Q$. robur, 19 Sep. 2016, R. Moisejevs (DAU600000476).

\section{ACKNOWLEDGEMENTS}

This work was supported by the Estonian Research Council under Grants PUT1017, IUT20-30, and IUT34-7; and Latvia's State Forests (LVM) under Grant 140619/S53. We are grateful to Māris Nitcis (Daugavpils University, Latvia) for help in preparing the maps, Kerry Knudsen (Czech University of Life Sciences, Prague, the Czech Republic) for proofreading of the manuscript, Tiina Randlane (University of Tartu, Estonia) for valuable comments on the paper, and to reviewers for their constructive comments.

\section{REFERENCES}

Āboliña A., Piterāns A., Bambe B., 2015: Lichens and bryophytes in Latvia: Checklist. - Salaspils.
Andrušaitis G., Vimba E., Piterāns A., 1996: Latvian Red Data Book. Rare and extinct plant and animal species. Mushrooms and lichens, 1. - Rīga.

ARtFakta, 2019: ArtDatabanken, SLU. https://artfakta.se/rodlistan [Accessed 14 August, 2019].

Auninsš A., LĀrmanis V., Rove I., Rūsiña S., Laime B. (eds), 2013: European Union Protected Habitats in Latvia. - Riga.

Barbero M., Etayo J., Gómez-Bolea A., 1995: Chemotypes of Cetrelia cetrarioides s. 1. (Lichenes) in the Iberian Peninsula. - Cryptogamic Botany, 5: 28-30.

Baroniņa V., 2017: Augu monitoringa metodika Natura 2000 teritorijās. www.daba.gov.lv/upload/ File/DOC.../MET_2017_augi_N2000_un_arpus. docx [Accessed 14 August, 2019].

Bilovitz P.O., Mayrhofer H., 2011: Epiphytic lichen mycota of the virgin forest reserve Rajhenavski Rog (Slovenia). - Herzogia, 24(2): 315-324.

Bely P., Golubkov V., Tsurykau A., Sidorovich E., 2014: The lichen genus Cetrelia in Belarus: distribution, ecology and conservation. - Botanica Lithuanica, 20 (2): 69-76.

Clerc P., 2004: Les champignons lichénisés de Suisse. - Cryptogamica Helvetica, 19: 1-320.

Culberson W.L., Culberson C.F., 1968: The lichen genera Cetrelia and Platismatia (Parmeliaceae).Washington.

Culberson W.L., Culberson C.F., 1976: Chemosyndromic variation in lichens. - Systematic Botany, 1(4): 325-339.

Degtjarenko P., Jüriado I., Lõhmus P., 2018: New Estonian records: Lichenized fungi. - Folia Cryptogamica Estonica, 55: 151-154.

Elix J.A., Mc CARThy P.M., 1998: Catalogue of the lichens of the smaller Pacific Islands. - Bibliotheca Lichenologica, 70: 1-361.

ESRI, 2011: ArcGIS Desktop, Release 10. - Redlands. Gilbert O.L., Purvis O.W., 2009: Cetrelia W.L. Culb. \& C.F. Culb. (1968). - In: Sмith C.W., Aptroot A., Coppins B.J., Fletcher A., Gilbert O.L., James P.W., Wolseley P.A. (eds), The lichen flora of Great Britain and Ireland: 296-297. - London.

Golubkov V., Matwiejuk A., Bely P., Tsurykau A., 2015: Revision of the genus Cetrelia (Lecanorales, Ascomycota) in the Białowieża Forest (Belarussian part). - Steciana, 19(3): 123-132. 
Hawksworth D.L., Blanco O., Divakar P.K., Ahti T., CRESPO A., 2008: A first checklist of parmelioid and similar lichens in Europe and some adjacent territories, adopting revised generic circumscriptions and with indications of species distributions. - The Lichenologist, 40(1): 1-21.

Hawksworth D.L., Divakar P.K., Crespo A., Ahti T., 2011: The checklist of parmelioid and similar lichens in Europe and some adjacent territories: additions and corrections. - The Lichenologist, 43(6): 639-645.

Hyvärinen E., Juslén A., Kemppainen E., UddstRöM A., Liukko U-M. (eds), 2019: The 2019 Red List of Finnish Species. - Helsinki.

Knezevic B., Mayrhofer H., 2009: Catalogue of the lichenized and lichenicolous fungi of Montenegro. - Phyton, 48(2): 283-328.

Kondratyuk S.Y., Popoval P., Lackovičovšút A., PIŠ́́t J., 2003: A catalogue of eastern Carpathians lichens. - Kiev.

Kurokawa S. (ed.), 2003: Checklist of Japanese lichens. - Tokyo.

Kukwa M., Motiejūnaité J., 2012: Revision of the lichen genera Cetrelia and Punctelia (Lecanorales, Ascomycota) in Lithuania with implications for their conservation. - Herzogia, 25(1): 5-14.

Kunwa M., Pietnoczko M., Czyżewska K., 2012: The lichen family Parmeliaceae in Poland. II. The genus Cetrelia. - Acta Societatis Botanicorum Poloniae, 81(1): 43-52.

Llimona X., Hladun N., 2001: Checklist of the lichens and lichenicolous fungi of the Iberian Peninsula and Balearic Islands. - Bocconea, 14: 5-58.

Lõhmus P., Marmor L., JÜriado I., Suija A., Oja E., Degtjarenko P., Randlane T., 2019: Red List of Estonian lichens: revision in 2019. - Folia Cryptogamica Estonica, 56: 63-76.

Mark K., Randlane T., Thor G., Hur J.S., OberMAYER W., SAAG A., 2019: Lichen chemistry is concordant with multilocus gene genealogy in the genus Cetrelia (Parmeliaceae, Ascomycota). Fungal Biology, 123(2): 125-139.

Mishra G.K., Upreti D.K., 2015: The lichen genus Cetrelia (Parmeliaceae, Ascomycota) in India. Phytotaxa, 236(3): 201-214.

Nordin A., Moberg R., Tønsberg T., Vitikainen O., Dalsätt Å., Myrdal M., Snitting D., Ekman S., 2011: Data from: Santesson's Checklist of Fen- noscandian Lichen-forming and Lichenicolous Fungi. Ver. 29 April 2011. http://130.238.83.220/ santesson/home.php [Accessed 14 August, 2019].

Obermayer W., Mayrhofer H., 2007: Hunting for Cetrelia chicitae (lichenized Ascomycetes) in the eastern European Alps (including an attempt for a morphological characterization of all taxa of the genus Cetrelia in Central Europe). - Phyton, 47(1-2): 231-290.

Orange A., James P.W., White F.J., 2001: Microchemical methods for the identification of lichens. - London.

Piterāns A., 2001: Checklist of the lichens of Latvia. - Latvijas Veǵetācija, 3: 5-45.

Randlane T., SAag A., 1991: Chemical and morphological variation in the genus Cetrelia in the Soviet Union. - The Lichenologist, 23(2): 113-126.

Randlane T., Saag A., Thell A., Ahti T., 2013: Third world list of cetrarioid lichens - in a new databased form, with amended phylogenetic and type information. - Cryptogamie Mycologie, 34(1): 79-84.

Regulations, 2013: Regulations Regarding the Establishment and Management of Micro-reserves, Their Conservation, as well as Determination of Micro-reserves and Their Buffer Zones. https:// likumi.lv/ta/en/en/id/253746 [Accessed $14 \mathrm{Au}-$ gust, 2019].

Santesson R., Moberg R., Nordin A., Tønsberg T., VITIKAINEN O., 2004: Lichen-forming and lichenicolous fungi of Fennoscandia. - Uppsala.

Sohrabi M., Ahti T., Urbanavichus G., 2007: Parmelioid lichens of Iran and the Caucasus Region. - Mycologia Balcanica, 4(1-2): 21-30.

Standards and Petitions Working Group, 2006: Guidelines for Using the IUCN Red List Categories and Criteria: Version 6.1. Prepared by the Standards and Petitions Working Group for the IUCN SSC Biodiversity Assessments Sub-Committee in July 2006. http://app.iucn.org/webfiles/ doc/SSC/RedList/RedListGuidelines.pdf [Accessed 14 August, 2019].

Stepanchikova I., Kukwa M., Notov A., HimelBRANT D., 2011: Novye dannye o lixenoflore Tverskoj oblasti. - Vestnik TvGU, Biologija i ekologija, 23: 137-142.

Thell A., Crespo A., Divakar P.K., Kärnefelt I., 
Leavitt S.D., Lumbsch H.T., Seaward M.R., 2012: A review of the lichen family Parmeliaceae - history, phylogeny and current taxonomy. Nordic Journal of Botany, 30(6): 641-664.

Urbanavichus G., ANDREev M., 2010: A checklist of lichen flora of Russia. - St. Petersburg.

Wei J.C., 1991: An enumeration of lichens in China. - Beijing.

Wirth V., Hauck M., Schultz M., 2013: Die Flechten Deutschlands, 1. - Stuttgart.

\section{CETRELIA GENTIES (LICHENIZUOTI AUKŠLIAGRYBŪNAI) REVIZIJA LATVIJOJE}

\section{Polina Degtjarenko, Rolands Moisejevs}

\section{Santrauka}

Buvo patikrinti visi DAU ir RIG herbariumuose laikomi Cetrelia pavyzdžiai (iš viso 98), surinkti Latvijoje. Inventorizacija patvirtino, kad šalyje aptinkamos trys Cetrelia genties rūšys: Cetrelia cetrarioides,
C. olivetorum ir C. monachorum. Pastaroji rūšis yra nauja Latvijos lichenobiotai. Straipsnyje pateikiami visų trijų rūšių paplitimo žemėlapiai bei jų buveinès Latvijoje, aptariamas rūšių apsaugos statusas. 